\title{
OPTICAL SENSOR OF FLAVONOIDS BASED ON LIQUID CRYSTAL
}

\author{
Orest Sushynskyi ${ }^{1}$, Romana Petrina ${ }^{2}$, Zoriana Gubriy ${ }^{2}$, Semen Khomyak ${ }^{2}$, Zinoviy Mykytyuk ${ }^{1}$, \\ Volodymyr Novikov ${ }^{2}$
}

${ }^{1}$ Lviv Polytechnic National University, Department of Electronic Devices, ${ }^{2}$ Lviv Polytechnic National University, Department of Technology of Biologically Active Substances, Pharmacy and Biotechnology

\begin{abstract}
In order to solve the problems associated with the express registration of the presence of biologically active substances in callus biomass, we propose the use of cholesteric liquid crystal (CLC) with a spiral structure as a material of a sensitive element of optical sensor of flavonoids. Cholesteric liquid crystal BLO62 is proposed to use as a sensitive element. Spectral characteristics of alcohol solutions of flavonoids (20\%, 40\%, $70 \%$ and $90 \%)$ were obtained. The interaction of CLC with quercetin was analyzed. The scheme of the primary information signal converter is developed in which the current from the photodetector is transmitted to the developed signal converter. The device is implemented with the common use Atmega 328 microcontroller manufactured by Atmel. Speciality of this structural scheme is its flexibility and versatility, which makes it easy to reconfigure the parameters of the firmware for the registration of various types of investigated mediums.
\end{abstract}

Keywords: optical sensor, liquid crystal, flavonoids, quercetin

\section{OPTYCZNY CZUJNIK FLAWONOIDÓW BAZUJĄCY NA CIEKŁYCH KRYSZTALACH}

Streszczenie. Aby rozwiązać problemy zwiazane z szybka analiza obecności substancji biologicznie czynnych w biomasie kalusa, proponujemy zastosowanie materiałów ciekłokrystalicznych o spiralnej strukturze supramolekularnej jako wrażliwego elementu czujnika optycznego flawonoidów. Proponuje się stosowanie cholesterycznego cieklego kryształu BLO62 jako wrażliwego elementu. Uzyskano charakterystykę spektralna roztworów alkoholowych flawonoidów (20\%, 40\%, 70\% i 90\%). Przeanalizowano interakcje cholesterycznego ciektego kryształu z kwercetyna. Opracowano schemat pierwotnego przetwornika sygnatu, w którym prąd z fotodetektora jest przesyłany do opracowanego przetwornika sygnałów. Urządzenie jest realizowane na bazie mikrokontrolera Atmega32 Atmega 328. Cecha tego schematu strukturalnego jest jego elastyczność i wszechstronność, co ułatwia rekonfigurację parametrów oprogramowania do rejestracji różnych typów badanych substancji.

Slowa kluczowe: czujnik optyczny, ciekły kryształ, flawonoidy, kwercetyna

\section{Introduction}

Currently, the use of plant raw materials for the production of pharmaceutical and cosmetic products for the prevention and treatment of many diseases is extremely relevant. Availability, low toxicity, high efficiency, low number of side effects and the presence of secondary metabolites are advantages of plant biomass use [9]. Plants containing flavonoids have antiinflammatory, spasmolytic, antihistamines, antibacterial, antioxidant effects.

Many medicinal plants are rare or endangered species, therefore the arsenal of medicinal plant material is limited. Application of modern methods of biotechnology and cell biology solves problems of obtaining biomass of plants, namely in vitro.

Grass and seeds of Arnica montana were harvested in the phase of full flowering (July - August) from the wild population of Ivano-Frankivsk region [13]. Arnica montana belongs to plants that are under threat of destruction and are listed in the Red Book of Ukraine. This plant contains the various biologically active substances (terpenoids, alkaloids, organic acids, vitamins, glycosides, phenolic compounds and flavonoids) and used in combination therapy for hepatitis, cholangitis and cholecystitis [8]. It is known that in the grass of Arnica montana there are such flavonoids - quercetin, isoquercetin, routine, quercetin pentaoxiaacetate, eriodictiol, hesperidin, campsferol, luteolin, apigenin, which can be explained by the antiasthmatic effect of flavonoids [14].

However, it is necessary to control the availability and content of specific biologically active compounds in cultivated biomass in vitro and its extracts. In order to solve the problems associated with the rapid analysis of the presence of biologically active substances in callus biomass, we propose the use of liquid crystal (LC) materials $[5,6,7,11]$ as a sensitive element of optical sensors. In the sensitive element of the primary transducers of optical sensors an information signal is formed due to the selective reflection (transmission) of light.

We propose to use as an active medium LC materials that are characterized by high sensitivity to external influences, namely temperature, pressure, humidity, action of gas molecules $[12,15]$. Among the wide range of electro-optical effects in LC materials, the effect of selective scattering in CLC was chosen. These LC materials are characterized by the presence of a spiral supramolecular structure. Works $[16,17,18]$ present the results of using a CLC active medium as an optical sensor of biological substances. Therefore, it is relevant to determine the concentration of flavonoids in alcohol solutions.

\section{Preparation of experimental samples and technique of investigation}

The object of the study was biologically active substances extracted from callus biomass of Arnica montana.

The biotechnological method of obtaining biomass of plants by in vitro cultivation method is used [10]. The method has many advantages, since the production of biomass does not depend on weather, seasons, soil quality, and callus biomass contains the same biologically active substances as the biomass of an intact plant. Callus biomass at $\mathrm{pH}$ 5.5-5.8 with the addition of $\beta$-indolylactic acid $(2.0 \mathrm{mg} / \mathrm{l}), \alpha$-naphthylacetic acid $(0.1 \mathrm{mg} / \mathrm{l})$ and kinetin $(0.5 \mathrm{mg} / \mathrm{l})$ was used to obtain and maintain a tissue culture. The cultivation was carried out with illumination of 2000 lux, a 16-hour photoperiod and a temperature of $23^{\circ} \mathrm{C}$. After 50 days, the callus biomass was obtained in light yellow color and loose consistency.

As an extractant, ethanol of different concentrations $(20 \%, 40 \%, 70 \%$ and $90 \%)$ was used. To study the dependence of flavonoids and the completeness of extraction from raw materials, alcohol extracts were obtained at various concentrations of the extractant. The presence of flavonoids was detected and confirmed using color reactions and UV spectroscopy. In the grass, Arnica montana contains $3.85 \pm 0.017 \%$, in callus biomass $4.04 \pm 0.008 \%$ of flavonoids.

A multicomponent cholesteric liquid cristal (CLC) mixture of BLO-62 produced by EM Industries, characterized by high temperature stability of optical characteristics, was chosen as an active LC medium. The nematic liquid crystal 5CB was added in to BLO-62. Concentration of nematic liquid crystal was chosen so that maximum selective reflection ranged within $400-850 \mathrm{~nm}$. The choosing of CNM was characterized by minimum optical transmission at $529 \mathrm{~nm}$ of wavelength at room temperature. The CNM with alcohol solution of callus biomass with the following percentage ratios: $20 \%, 40 \%, 70 \%$ 
and $90 \%$ was studied. Spectral studies were using by means of a spectrophotometer USB-2000 in the range of wavelengths of $200-1000 \mathrm{~nm}$

In the work [8] the technique of experimental investigations and processing the obtained results is described. The method of obtaining experimental mixtures based on a CNM with the addition of solutions (aqueous, alcohol) of biological substances is considered in the paper [12].

\section{Results and discussion}

On the basis of the spectral studies carried out, spectral dependences were obtained. The typical dependence is shown in Fig. 1.

As can we was concluded from the all spectrals dependencies of the addition of alcoholic solution of flavonoids in the CNM, there is a shift of the minimum transmission in the longwavelength region of the spectrum (for mixtures of $20 \%, 40 \%$ and $70 \%$ ) and in the short-wave region with an increase in the percentage composition of the alcohol solution (for $90 \%$ ).

We observed the linear changing of wavelength of minimum transmission versus of concentration of quercetin alcohol solutions.

As can be seen from Fig. 2 the course of the dependence of the minimum wavelength of the optical transmission from the concentration of $70 \%$ and $90 \%$ (curve 3 and 4 ) of the alcohol solution in CNM are observed the shift of minimum wavelength of the optical transmission into smaller wavelengths.

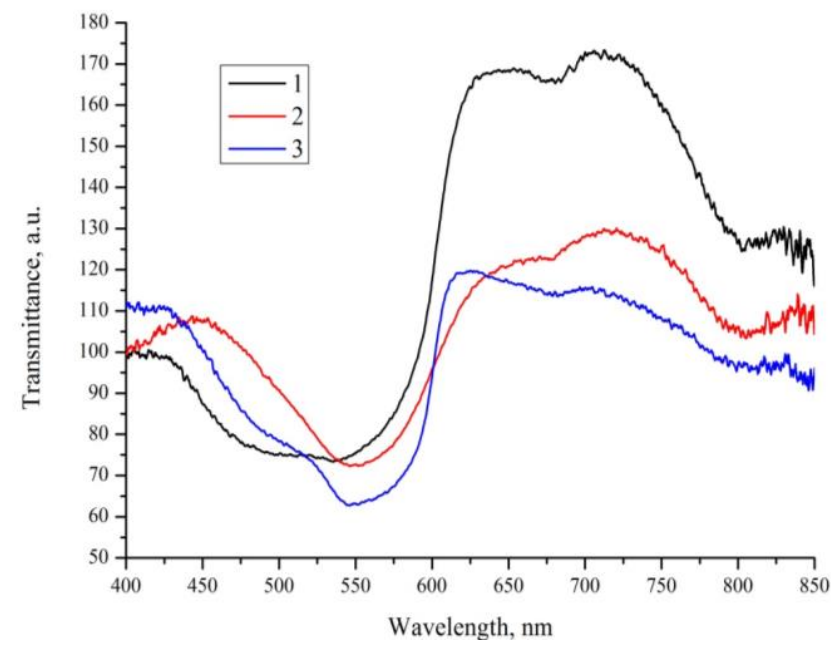

Fig. 1. The typical spectral dependencies of CNM with $20 \%$ alcohol solution of quercetin in callus biomass: 1 - $13.00 \mathrm{wt}$.\% (alcohol solution); $2-26.09 \mathrm{wt} . \%$ (alcohol solution); $3-30.88 w t$. (alcohol solution)

Explaining the process of interaction of CNM with flavonoids, we can assume the following. Quercetin molecule is typical flavonoid (Fig. 3) and contains the $\pi$-electron aromatic structure, in solution it has a planar structure with a high degree of polarity. Due to the extended $\pi$-electron system in the quercetin molecule, an effective dispersion interaction with the surrounding LC medium is provided. In addition, in the quercetine molecule, there are five phenolic groups, and in the LC molecule there are many carboxyl groups that can form a hydrogen bonds with each other. This hydrogen bond is not strong but sufficient for effective interaction. A complex is formed between the impurity molecules (quercetin) and the LC and its deformation takes place.

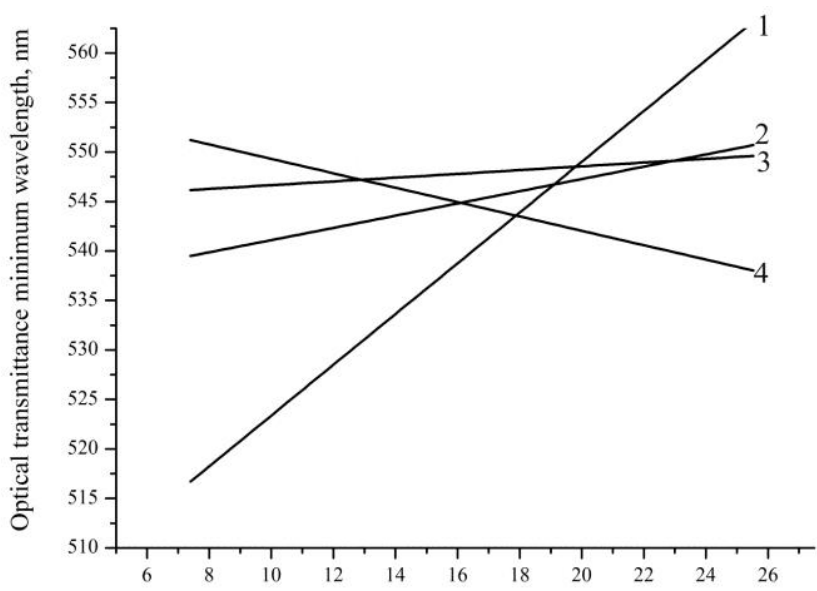

Concentration of spiritus solution of quercetin in CLC BLO62, wt.\%

Fig. 2. Dependence of the minimum wavelength of optical transmission on the concentration of alcohol solution of quercetin in callus biomass in CNM $1-20 \%, 2-40 \%, 3-70 \%, 4-90 \%$<smiles>O=c1c(O)c(-c2ccc(O)c(O)c2)oc2cc(O)cc(O)c12</smiles>

Fig. 3. Structural formula of quercetin molecule (2-(3,4-dihydroxyphenyl)-3,5,7trihydroxy-4H-chromen-4-one

\section{The principal electrical realization of flavonoids optical sensor}

The principle of operation of an optical sensor lies in the process of registering an information signal from the source of radiation that has passed through the active medium to the photodetector $[10,16,17,18]$. In our case, the information signal is the wavelength $[1,2,3]$.

The device (Fig. 4) is implemented with the use of the Atmega 328 microcontroller. The main structural elements are the light source, the active medium, the photodetector, the microcontroller, the interface and the elements of the signal transducer - the input amplifier, the clock detector, the integrator $[2,3,4]$.

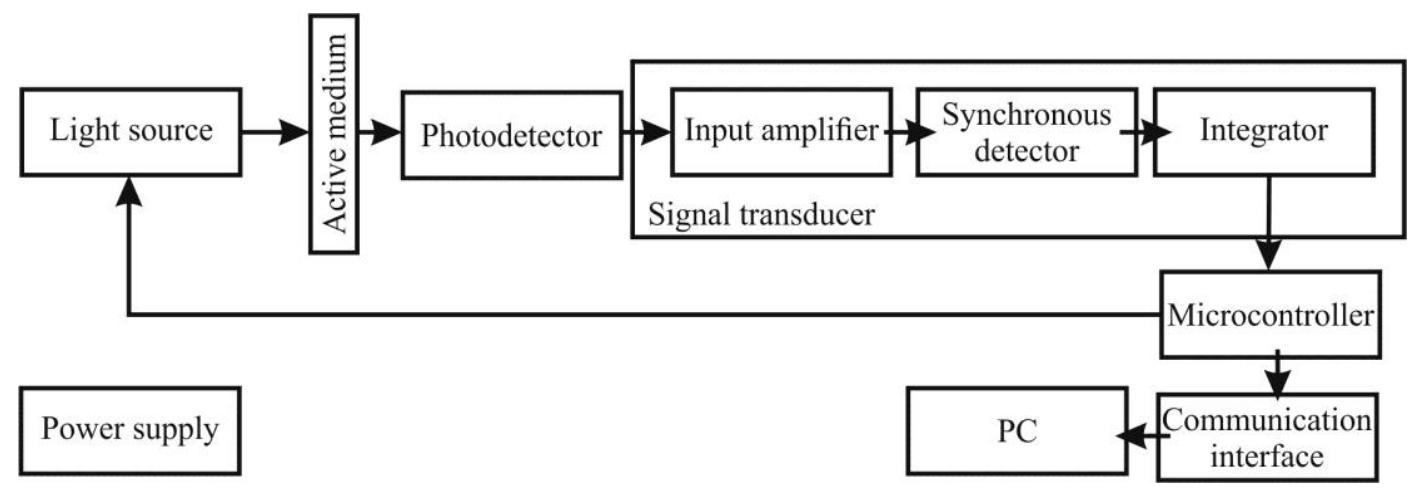



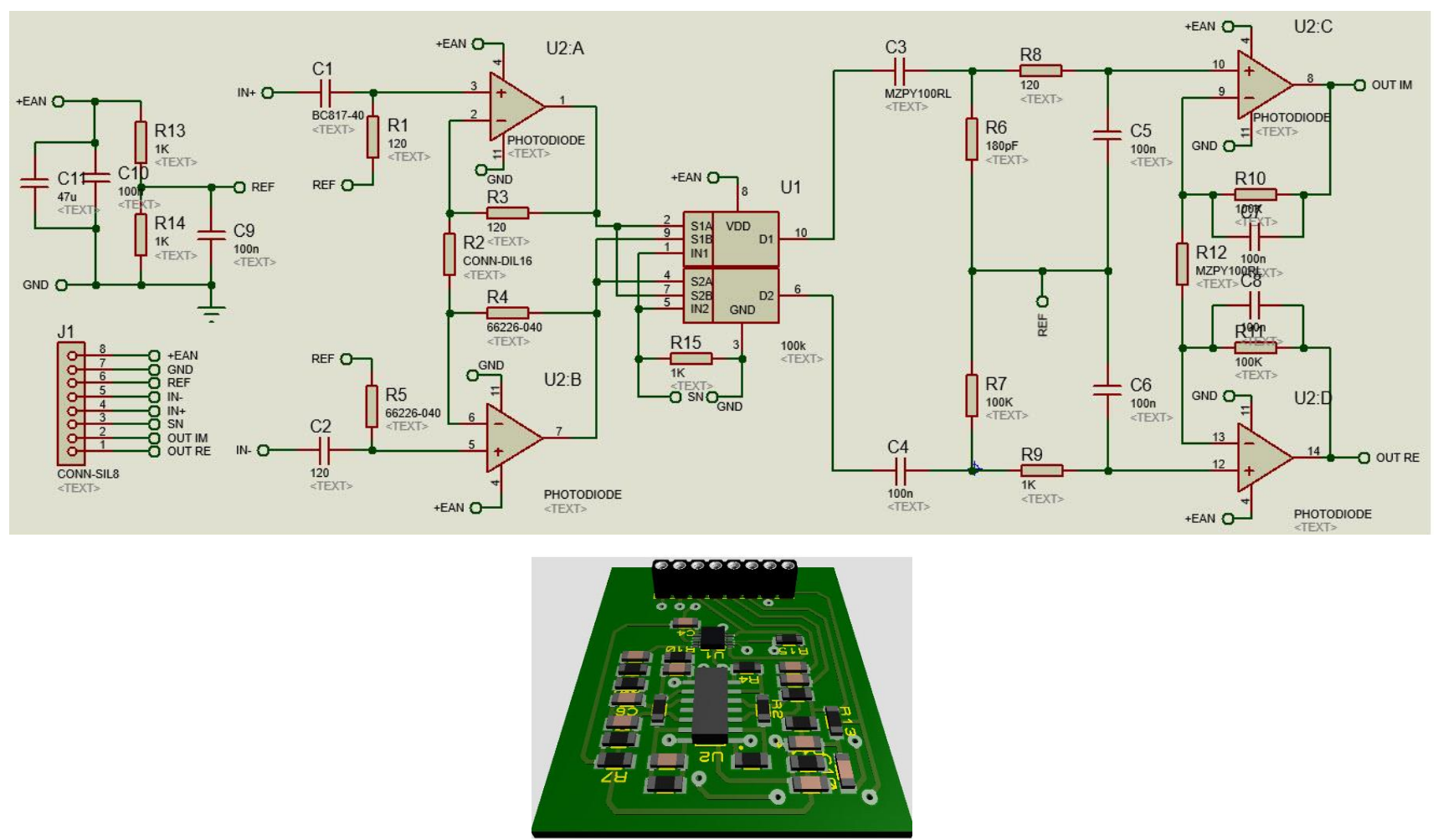

Fig. 5. Electric circuit diagram of the signal converter and its $3 D$ realization

The light source forms an microcontroller modulated optical signal, which crosses the active medium by photodetector registration. The informative signal thus formed after the previous amplification is detected with the subsequent integration and enters the analog input of the microcontroller. Further processing of the received signal is carried out programmatically according to the algorithm of the created software, which is placed in the built-in memory of the microcontroller. Output measurements via the interface unit are transmitted to the PC for their digital and graphical representation.

The peculiarity of this structural scheme is its flexibility and versatility, which makes it easy to reconfigure the parameters of the firmware for the registration of various types of investigated environments.

Figure 5 depicts the electrical principle diagram of the signal converter, which is implemented using modern energy-efficient microelectronic components in particular amplifiers AD8544 and switch AG736.

The simulation was performed and the optimal operating mode of the sensor was selected in the Proteus software environment.

\section{Conclusion}

1) As can been concluded cholesteric-nematic mixture is useful to designed the sensitive element of flavonoids optical sensor for detection in callus biomass.

2) Take in to account the influence, we can to suggest the extended $\pi$-electron system in the flavonoids (quercetin) molecule, an effective dispersion interaction with the surrounding LC medium.

3) The proposed structural scheme is its flexibility and versatility, which makes it easy to reconfigure the parameters of the firmware for the registration of various types of biological investigated mediums.

\section{References}

[1] Barylo G., Holyaka R., Prudyus I., Fabirovskyy S.: Parametric analysis of galvanostatic type impedance measuring front-end. Proceedings of the 4th International scientific-practical conference problems of infocommunicationsscience and technology PIC S\&T, Kharkiv 2017, 323-326.

[2] Barylo G., Holyaka R., Virt V., Vezyr F.: Method of analysis errors of measuring conversion of impedance spectroscopy with activation nonharmonic signals. Scientific Journal of the Ternopil National Technical University 86/2017, 108-116.

[3] Barylo G., Mykytyuk Z., Holyaka R., Vistak M., Virt V., Vezyr F.: Parametric analysis of input circuits of galvanostatic type impedance measuring transducers. Sensors \& Transducers 214/2017, 64-68.

[4] Barylo G.I., Holyaka R.L., Virt V.V., Vezyr F.F.: Parametric analysis of synchronous detector devices of impedance spectroscopy. Scientific and technical journal Applied radio electronics 16/2017, 41-45.

[5] Bashtyk Y., Bojko O., Fechan A., Grzyb P., Turyk P.: Primary converters for optical sensors of physical values based on polymer dispersed cholesteric liquid crystal. Molecular Crystals and Liquid Crystals, 642/2017, 41-46 [DOI: 10.1080/15421406.2016.1254509].

[6] Bishchaniuk T.M., Balaban O.V., Shvets R.Y., Grygorchak I.I., Fechan A.V., Lukiyanets B.A., Ivashchyshyn F.O.: Electronic processes and energy storage in inorganic/organic nanohybrids. Molecular Crystals and Liquid Crystals 589/2014, 132-140 [DOI: 10.1080/15421406.2013.872404].

[7] Dudok T.H., Savaryn V.I., Krupych O.M., Fechan A.V., Lychkovskyy E., Cherpak V.V., Pansu B., Nastishin Y.A.: Lasing in imperfectly aligned cholesterics. Applied Optics 54/2015, 9644-9653 [DOI: 10.1364/AO.54.009644]

[8] Kobsar A.Ya.: Pharmacognosy in medicine. Medecine, Kyiv 2007.

[9] Konechna R., Khropot O., Petrina R., Kurka M., Gubriy Z., Novikov V.: Research of antioxidant properties of extracts of the plants and the callus biomass. Asian Journal of Pharmaceutical and Clinical Research 10/2017, 182 185.

[10] Konechna R.T, Petrina R.O.: Extracts of callus and vegetative raw materials Arnica montana L. Pharmaceutical Clinical Pharmacy, Pharmacotherapy and Medical Standardization 1/2015, 100-104.

[11] Mikityuk Z., Fechan A., Semenova J.: Liquid crystal material for light modulators on the base of cholesteric-nematic phase transition. Proceedings of SPIE - The International Society for Optical Engineering, Electronic Imaging: Science \& Technology, 1996. 196-208 [DOI: 10.1117/12.235353].

[12] Mykytyuk Z., Fechan A., Petryshak V., Barylo G., Boyko O.: Optoelectronic multi-sensor of $\mathrm{SO} 2$ and $\mathrm{NO} 2$ gases. Proceedings of 13th International Conference on Modern Problems of Radio Engineering, Telecommunications and Computer Science TCSET, Lviv 2016, 402-405 [DOI: 2016.7452070]. 
[13] Nad B. B.: Bioecological and biotechnological bases for preservation of the gene pool Arnica montana L. in Transcarpathia. Timpani, Uzhhorod - Berehove 2014.

[14] Pokorny J.: Application of phenolic antioxidants in food products. EJEAF Chem. 7/2008, 3320-3324.

[15] Sushynskyi O., Prystay T., Mykytyuk Z.: The nanocomposite on the base of liquid crystal material with aluminum nitride for sulfur dioxide optical sensor. Proceedings of SID International Symposium Digest of Technical Papers EuroDisplay, 2015, 92 [DOI:92 10.1002/sdtp.10507].

[16] Sushynskyi O., Vistak M., Dmytrah V.: The sensitive element of primary transducer of protein optical sensor. Proceedings of the 13th International

\section{D.Sc. Orest Sushynskyi}

e-mail:orest.y.sushynskyi@lpnu.ua

Associate professor at the Department, Institute Electronic Devices of Telecommunication, Radioelectronics, and Electronic Devices, Lviv Polytechnic National University. He has published over 50 journals and conference papers in the area of liquid crystal materials. His scientific interest is focused on modification of liquid crystal materials by nanoscale impurities.

ORCID ID: 0000-0002-2661-6458

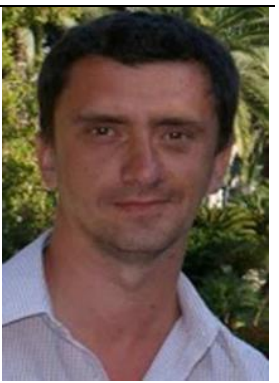

\section{Ph.D. Romana Petrina}

e-mail: romanna.o.petrina@lpnu.ua

Associate Professor at the Department of Technology of Biologically Active Substances, Pharmacy and Biotechnology, Institute of Chemistry and Chemical Technologies, Lviv Polytechnic National University. Scientific interests: obtaining biomass of medicinal plants in vitro and its research, biologically active substances of plants; biopolymers of medical purpose.

ORCID ID: 0000-0002-5416-1999

\section{D.Sc. Zinoviy Mykytyuk \\ e-mail: zm.mykytiuk@gmail.com}

Professor at the Department, Institute Electronic Devices of Telecommunication, Radioelectronics, and Electronic Devices, Lviv Polytechnic National University. He has published over 500 journal and conference papers in the area of liquid crystal materials. Prof. Mykytyuk is a member of New York Academy of Sciences, Mongolian Academy of Sciences, and Associated Soros Professor. $\mathrm{He}$ is a member of the Optical Society of America, SPIE, and SID.
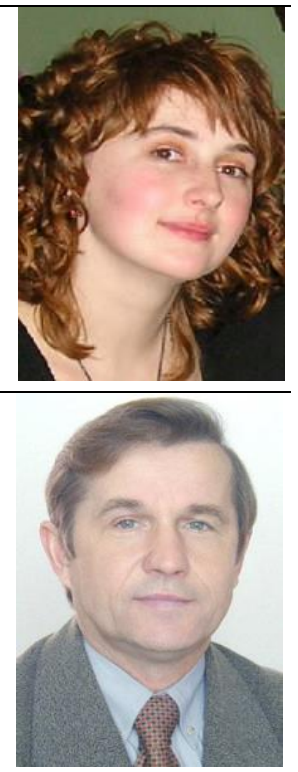

ORCID ID: 0000-0002-1944-2015
Conference Modern Problems of Radio Engineering, Telecommunications and Computer Science, TCSET, Lviv 2016 418-421.

[17] Vistak M., Dmytrah V., Horbenko Ju.: Investigation of spectral characteristics of cholesteric liquid crystals at carbohydrates influence. Eastern European Journal of Enterprise Technologies 6/2016, 18-22 [DOI:10.15587/17294061.2015.65481].

[18] Vistak M., Dmytrah V., Mykytyuk Z., Petryshak V., Horbenko Y.: A liquid crystal-based sensitive element for optical sensors of cholesterol. Functional Materials 24/2017, 687-691 [DOI: 10.15407/fm24.04.687].

\section{Ph.D. Zoriana Gubriy}

e-mail: gubrzor@gmail.com

Associate Professor at the Department of Technology of Biologically Active Substances, Pharmacy and Biotechnology, Institute of Chemistry and Chemical Technologies, Lviv Polytechnic National University. Scientific interests: synthesis and study of properties of derivatives of $1,2-$ and 1,4-naphthoquinones; study of biological activity of synthesized compounds.

ORCID ID: 0000-0003-2533-6857

\section{Ph.D. Semen Khomyak}

e-mail: semen.v.khomyak@lpnu.ua

Associate Professor at the Department of Technology of Biologically Active Substances, Pharmacy and Biotechnology, Institute of Chemistry and Chemical Technologies, Lviv Polytechnic National University. Scientific interests: synthesis of new derivatives of 1,4-naphthoquinone, hindered phenol and amino acids.

ORCID ID: 0000-0003-1931-1688

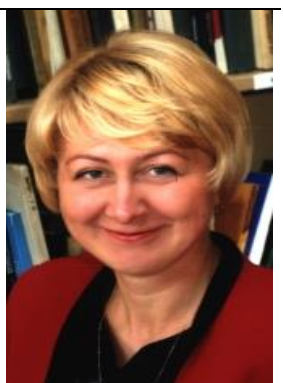

\section{Sc.D. Prof. Volodymyr Novikov}

e-mail: volodymyr.p.novikov@lpnu.ua

Head of the Department of Technology of Biologically Active Substances, Pharmacy and Biotechnology, Institute of Chemistry and Chemical Technologies, Lviv Polytechnic National University. Scientific interests: search and development of new drugs of synthetic, biotechnological and natural origin. Biological activity of new compounds among substances of quinone structure, N-, S-, Pheterocyclic derivatives, thiosulfate esters and biopolymers.

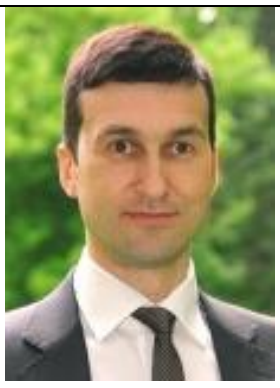

ORCID ID: 0000-0002-0485-8720 